\title{
Proceeding
}

Supplementary Issue: Spring Conferences of Sports Science. Costa Blanca Sports Science Week, 26-28 April 2018. Calpe. Alicante, Spain

\section{Sport and exercise at university: How much do students really do?}

\author{
CAROLINA CASTAÑEDA-VÁZQUEZ1 $\triangle$, ROSA Ma ALFONSO-ROSA², JESÚS DEL POZO-CRUZ², \\ FÁTIMA CHACÓN-BORREGO 1 \\ ${ }^{1}$ Research Group HUM-507, Faculty of Educational Sciences, University of Seville, Seville, Spain \\ ${ }^{2}$ Research Group CTS-972, Faculty of Educational Sciences, University of Seville, Seville, Spain
}

\begin{abstract}
There is irrefutable evidence regarding the effectiveness of regular physical exercise for preventing disease and its relation to health status at any age. As academic and formative institutions par excellence, universities should do their utmost to encourage students to do sport. This study analysed how much physical exercise students did using university services and facilities. We conducted a descriptive and correlational crosssectional study on a sample of 1085 subjects (569 women; average age 21 years, $\sigma=3.05$ ), with a randomized design, stratified by faculty and gender (confidence level of $95.5 \%$; error 3.01). In a personalized interview, subjects completed a questionnaire about their physical activity habits. Main results showed most students were aware of the sports activities available at university, while only a few had the university sports card. We found correlations between gender, physical exercise and federated sport, with knowledge of sports services, possession of the sports card and the promotion of performance-oriented sport at university. Due to the unquestionable benefits of physical activity, university students are a key population for the promotion of sport. Key words: SPORT, UNIVERSITY, PHYSICAL ACTIVITY, COLLEGE, STUDENTS.
\end{abstract}

\section{Cite this article as:}

Castañeda-Vázquez, C., Alfonso-Rosa, R., Del Pozo-Cruz, J., \& Chacón-Borrego, F. (2018). Sport and exercise at university: How much do students really do? Journal of Human Sport and Exercise, 13(2proc), S231-S239. doi:https://doi.org/10.14198/ihse.2018.13.Proc2.07

\footnotetext{
Corresponding author. Faculty of Educational Sciences, University of Seville, Seville, Spain. http://orcid.org/0000-0002-0647$\underline{507 X}$

E-mail: carolinacv@us.es

Supplementary Issue: Spring Conferences of Sports Science. Costa Blanca Sports Science Week, 26-28 April 2018. Calpe. Alicante, Spain.

JOURNAL OF HUMAN SPORT \& EXERCISE ISSN 1988-5202

(c) Faculty of Education. University of Alicante

doi: 10.14198/jhse.2018.13.Proc2.07
} 


\section{INTRODUCTION}

There is irrefutable evidence in a large number of studies reaffirming the benefits of physical activity (PA) and sports on health (Celis-morales et al., 2015; Donnelly et al., 2013; Fanning et al., 2018; Kelley, Kelley, Roberts, \& Haskell, 2012; Nakamura et al., 2014; Song et al., 2012), and the general public is increasingly aware of the importance of doing sport to optimize their bodies' performance at all levels.

Recent research into the habits of the Spanish regarding sport (García-Ferrando \& Llopis-Goig, 2010; Ministerio de Educación Cultura y Deporte, 2015) has underlined a growing interest in doing PA and a positive attitude towards sport. Similarly, a new conception of sport, oriented towards leisure, health and improving quality of life, has been taking hold socially over the last decade. These same surveys have found that sporting activity is moving away from competitive sport towards healthier ways of using one's free time, by including sport within healthier lifestyles.

In their role as educational institutions, Spanish universities have set themselves the goal of promoting sport at university, by organizing and facilitating sports for the student community and, at the same time, ensuring that this is compatible with students' academic commitments (Government of Spain, 2007).

The Comprehensive Plan for Physical Exercise and Sport (Consejo Superior de Deportes [CSD], 2010) refers to the importance of sport at university for two main reasons. On the one hand, as university is the final stage in people's education, it represents the last chance to reinforce habits to improve their quality of life. On the other, PA contributes to the development of an integral education for students.

In fact, measure number 40 of that document (CSD, 2010) includes the constitution of a Spanish Network of Healthy Universities (REUS, 2011), whose objectives include: strengthen the university as an environment that promotes the health of the university community and society as a whole (p.5).

This plan identifies the university sector as one of the most interested in sports practice (due in part to the youth of its students), which should lead university heads to propose physical exercise programs to meet their needs and interests.

Finally, this document and other publications (Alonso, Rial, \& Rial, 2013) stress the need to gather information and research at different universities in order to increase the scarce knowledge currently available on university sport, and track its evolution over time.

For the above reasons, this paper aims to establish how much information students have about university sports, and their interest in the range of sports on offer. It also intends to analyse their participation in university sports activities and looks at variables that could influence these factors.

\section{METHODS}

\section{Design and Participants}

This research was part of a larger study into PA habits and other habits related to the health and quality of life of students at the University of Seville. It was a non-experimental, descriptive and correlational crosssectional study. 
The sample consisted of 1,085 students, 569 female (52\%) and 516 male (48\%), with an average age of 21 $(\sigma=3.05)$, selected through stratified random sampling (proportional affixing) according to centre and sex; this implied a $95 \%$ confidence level and a maximum sampling error of $\pm 5 \%$.

\section{Instruments}

We applied a closed and validated ad hoc questionnaire (Castañeda-Vázquez, Díaz-Martínez \& GonzálezCampos, 2017; Castañeda-Vázquez, Zagalaz, Arufe, \& Campos-Mesa, 2018; Castañeda, Campos, \& del Castillo, 2016), from which we selected the following variables for this study: students' knowledge of the university's sports activities; possession of the university sports card; type of sport that should be prioritized by the university (sport for leisure and recreation, performance sport and health-oriented PA); interest in receiving more information about the sports offered by the university; regularity of PA and possession of federation licenses or federated competitive practice. The gender of the students was also analyzed as a socio-demographic variable.

Gender was recorded on one dichotomous nominal scale (male, female). All other variables were assessed using another dichotomous nominal scale (yes, no).

\section{Procedure}

Data collection was carried out in different faculties and centres belonging to the University of Seville during class hours. The subjects surveyed were informed about the objectives of the study and agreed to participate in the study with prior informed consent. They completed the questionnaire after receiving instructions from the researchers, who were always present to clarify any doubts that might be raised by the respondents.

\section{Data analysis}

We used IBM SPSS $®$ Statistics 24.0 software for the data analysis, performing a descriptive analysis using frequencies and percentages. Bivariate correlations were made using the Spearman correlation coefficient to analyse the level and relationship between the variables.

\section{RESULTS}

Table 1, below, provides descriptive data on students' knowledge and conception of sport and university sports, as well as on the practice of PA at the time of the survey.

The following data show (Table 1) show a large percentage of students who are familiar with the university sports service (close to $70 \%$ ). Of this percentage, only $15 \%$ of the population said they had a sports card that gave them access to all university sports facilities. Regarding the students' conception about the type of sport that should be prioritized at university, the students considered that sport oriented to leisure and recreation should be the priority (42.8\%), followed by health-oriented PA (35.6\%) and then performance sport (16.1\%). As for the practice of sports, almost half of the population (46.3\%) reported performing some type of PA on a regular basis, although only $6.5 \%$ of them competed at a federated level in some form of sports.

Table 2, below, shows the descriptive analysis of the variables according to students' gender, the practice of PA and the sports practiced at a federative level. 
Table 1. Descriptive data on PA practice and sport at university.

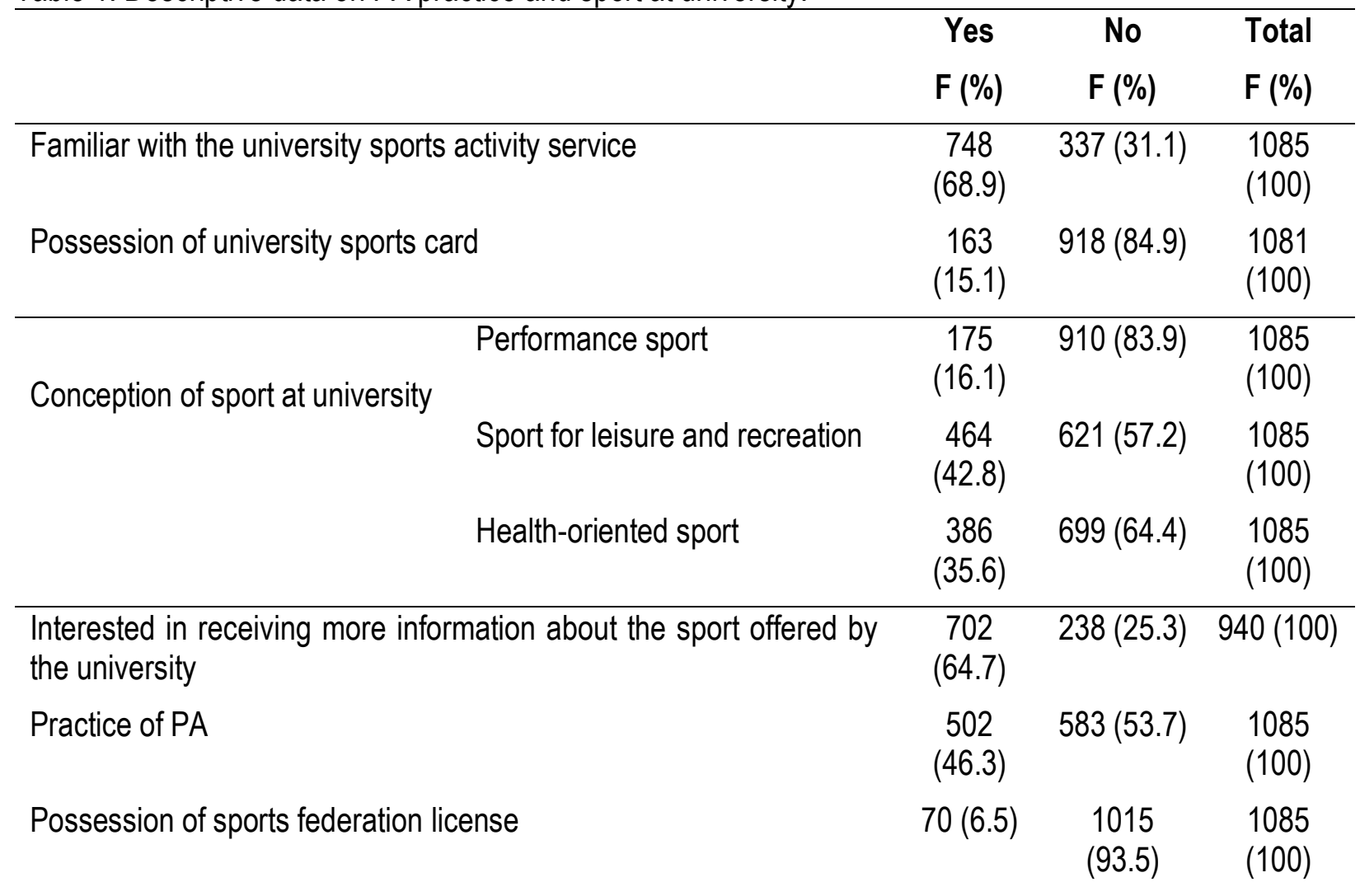

Table 2. Descriptive data of PA and sport at university according to gender, practice of PA and the practice of federated sport.

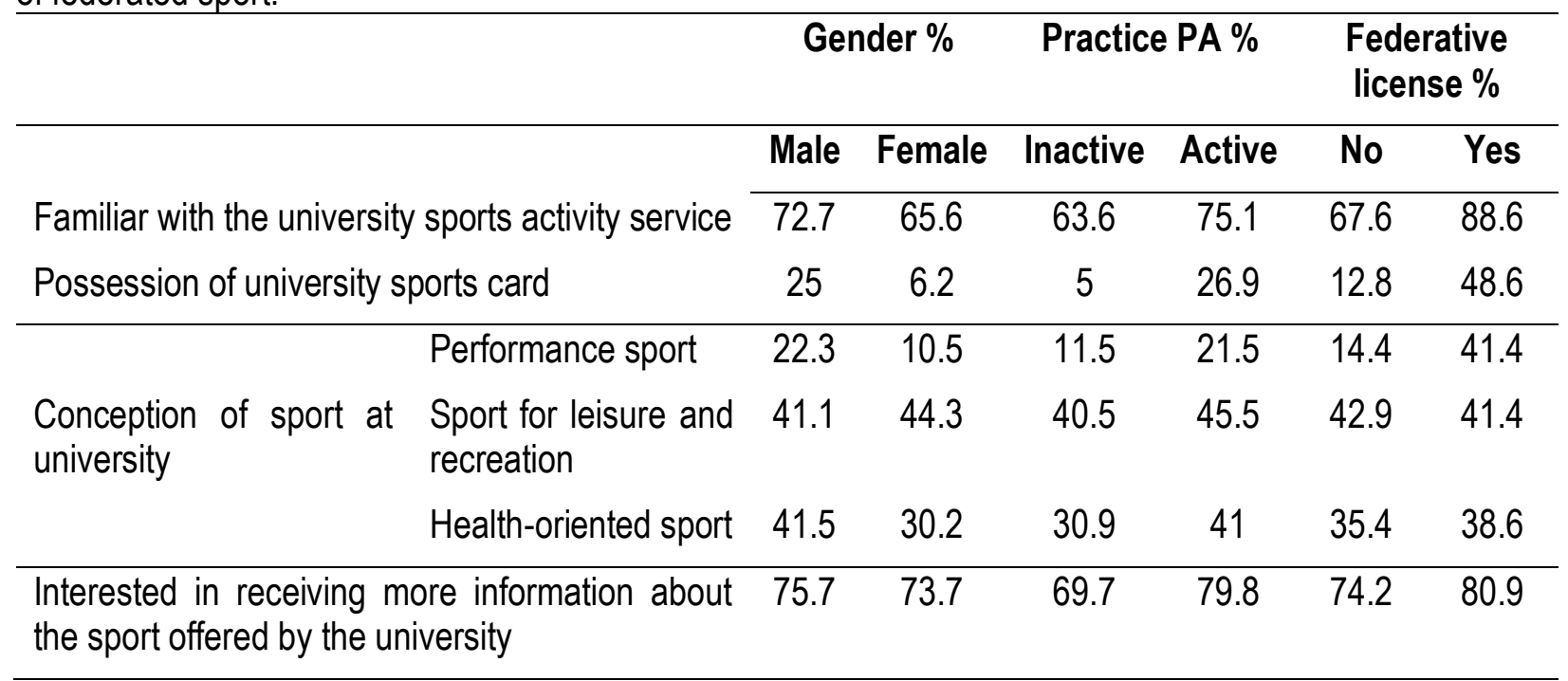

The results of the correlational analysis (Table 3) show that there were negative correlations between students' gender and knowledge of the university's sports service, possession of the university sports card and the conception of university sport, prioritizing health-oriented sports. With respect to PA practice, correlations were also found, in this case positively, between this variable and those mentioned above: 
knowledge of the university's sports service, possession of the university sports card and the conception of university sport prioritizing health-oriented sports, as well as the performance aspect of university sports and interest in receiving more information about the sports offered by the university.

In the case of competitive sport at a federated level, Table 3 shows positive correlations between this variable and knowledge of the university's sports service, possession of the university sports card and the conception of performance-oriented university sport.

Table 3. Bivariate correlations between university sports and gender, PA practice and federated sports practice.

\begin{tabular}{|c|c|c|c|}
\hline & Gender & $\begin{array}{c}\text { Practice of } \\
\text { PA }\end{array}$ & $\begin{array}{l}\text { Federation } \\
\text { license }\end{array}$ \\
\hline Familiar with the university sports activity service & $-.077^{* *}$ & $.124^{* *}$ & $.111^{* *}$ \\
\hline Possession of university sports card & $-.263^{* *}$ & $.305^{\star *}$ & $.246^{\star *}$ \\
\hline Performance sport & -.159 & $.136^{* *}$ & $.181^{* *}$ \\
\hline \multirow[t]{2}{*}{$\begin{array}{l}\text { Conception } \\
\text { university }\end{array}$} & .032 & .050 & -.007 \\
\hline & $-.117^{* *}$ & $.106^{* *}$ & .016 \\
\hline $\begin{array}{l}\text { Interested in receiving more information about the sport } \\
\text { offered by the university }\end{array}$ & -.023 & $.116^{* *}$ & .040 \\
\hline
\end{tabular}

Note: Spearman's coefficient ${ }^{* *} p<.01{ }^{*} p<.05$

\section{DISCUSSION}

The data show that the majority $(68.9 \%)$ of the students at the University of Seville are familiar with the university sports activities service, although more than half of them $(65 \%)$ would like to receive more information about the sports on offer, while only $15 \%$ have the sports card that gives access to these services.

Very similar data to these have been obtained in previous studies. The CSD study El modelo del Deporte Universitario español [The model of Spanish university sport] (CSD, 2005) found that Spanish university students knew little about the sports services available at their universities. Likewise, it found that only $34.6 \%$ of physically active Spanish students did sport at their universities.

Several authors have pointed to this tendency for university students to do PA outside the university (GómezLópez, 2005; Rico, 2017; Ruiz-Juan \& Gómez-López, 2005). At the University of Huelva (Castillo-Viera, 2006), barely $16 \%$ of students said they had the sports card. Likewise, at the University of Burgos (Corbi Santamaría, 2017), only 9.6\% of students had the sports card. While at La Rioja (Sanz, 2005), more than $70 \%$ did PA in non-university facilities with only $30 \%$ doing this in university installations.

At Galician universities (Alonso-Fernández \& García-Soidán, 2010), 63\% of students did not do sport at university; while a percentage of students (slightly over 23\%) were unaware of the activities and sports facilities provided by their university. While half of the active and inactive students stated that the information about the sports service was sufficient, a relatively high percentage $(34 \%$ and $35 \%$ of the active and inactive students, respectively) considered that the information provided by the service was insufficient. 
On this point, there were no major differences between the opinions of active and inactive Galician students. However, in the case of university students in Seville, we found correlations between the practice of PA and the knowledge of the sports activities service and interest in receiving more information about the sports available. Those students who did PA were better informed and showed greater interest in receiving more information about university sports than their physically inactive peers.

Similarly, our analysis found correlations between students' gender and the practice of federated sport. Thus, federated sport correlated with knowledge of university sports services and possession of sports cards.

As for the type of sport that should be prioritized at university, students considered that recreational sport and health-oriented PA should be given priority, over and above performance sport. However, a study at the University of Murcia (Pavón-Lores \& Moreno-Murcia, 2006) found that the highest percentage of students $(67.2 \%)$ considered that the university should promote both types of sport: performance sport and sport for all; while a slightly lower percentage considered that sport for all should be promoted in particular, with the smallest number opting for performance sport.

Correlations have been observed between these conceptions of university sport and the practice of PA, gender or the possession of federation licenses. Thus, the practice of PA correlated with the promotion of performance sports, as well as competitive and federated sports practice. While the male gender and PA also correlated with the promotion of sports or health-oriented PA.

Several studies have already found (Gómez-López, 2005; Ruíz, 2001) that university students tend to be involved more in non-competition sport, preferring other activities to traditional competitive sports. Some authors have referred to an evolution in university sport, from a strictly competitive approach to a perspective focusing more on the promotion of healthy PA throughout the university community (Alonso, 2009; Alonso \& García-Soidán, 2011; Alonso et al., 2013). However, the data recorded in this study did not tie in entirely with these findings. Hence, while most students maintained a view that university sport should be oriented towards leisure, recreation and health, over and above performance, the correlations showed a closer relationship between university sports practice and men, PA practitioners and federated sport. This may indicate the continued importance of university sports competitions and the link between the range of sports activities offered by universities and the competitive and performance environment. This orientation should not be underestimated in any case and may indeed be compatible and complementary to leisure and recreation sports and health-oriented PA.

However, a detailed comparison of data between different universities would be no easy task due, on the one hand, to the scarcity of in-depth studies analysing sports activity at university and, on the other, to the inherent diversity of those studies that have been done. In fact, the Comprehensive Plan for Physical Activity and Sport (CSD, 2010) makes the following statement:

...university sport is saddled with a series of studies from diverse approaches and with different findings that make it difficult to gain an accurate picture of the current situation. Furthermore, this represents an obstacle to the generation of valid and reliable indicators and units of measurement that would tell us about the state of university sport and how it evolves over time (p.58).

For these reasons, we consider it essential to continue with this line of research. There seems to be a strong argument for universities to establish common patterns of analysis to facilitate the comparison of information. 
Longitudinal studies should also be conducted to analyse the evolution of sport at university and gather records of students' sports activities throughout their time at university.

\section{CONCLUSIONS}

The following conclusions can be drawn from the objectives set at the beginning of this research:

Most students are familiar with the university sports service, although few have the sports card enabling them to use university sports facilities. Hence, it is logical that students who take physical exercise are better informed and more interested in receiving more information about university sports than inactive students.

Similarly, men and federated sport correlate with knowledge of university sports services and possession of sports cards.

The students surveyed considered that sport oriented towards leisure and recreation should be prioritized at university, followed by health-oriented PA, and then performance sports. However, although this is the opinion of most students, the correlations recorded showed a closer relationship between university sports practice with men, PA practitioners and federated sport.

\section{REFERENCES}

Alonso-Fernández, D., \& García-Soidán, J. L. (2010). Motivación hacia la práctica físico-deportiva de universitarios gallegos. Revista de Investigación En Educación, (8), 128-138. Retrieved from http://webs.uvigo.es/reined/ojs/index.php/reined/article/view/135

Alonso, D. (2009). Niveles de Condición Física Saludable y hábitos de práctica físico-deportiva en alumnado universitario. Universidad de Vigo.

Alonso, D., \& García-Soidán, J. (2011). Valoración de la condición física saludable en universitarios gallegos. Revista Internacional de Medicina y Ciencias de La Actividad Física y El Deporte, 11(44), 781-790.

Alonso, D., Rial, J., \& Rial, A. (2013). Evaluación de la calidad percibida de los servicios deportivos en el ámbito universitario. Revista de Psicología Del Deporte, 22(1), 143-150.

Castañeda-Vázquez, C., Díaz-Martínez, X., \& González-Campos, G. (2017). Consumo De Drogas En La Universidad. Análisis En Función Del Sexo Y La Práctica De Actividad Física Drug Consumption in University. Analysis According to Gender and Sport Practice. Health and Addictions, 17(172), 169177.

Castañeda-Vázquez, C., Zagalaz, M. L., Arufe, V., \& Campos-Mesa, M. C. (2018). Motivos hacia la práctica de actividad física de los estudiantes universitarios sevillanos. Revista Iberoamericana de Psicología del Ejercicio y el Deporte 13(1), 79-89.

Castañeda, C., Campos, M., \& del Castillo, O. (2016). Actividad Física y Percepción de Salud de los Estudiantes Universitarios. Revista Facultad de Medicina Universidad Nacional de Colombia, 64(2), 277-284. https://doi.org/10.15446/revfacmed.v64n2.53068

Castillo-Viera, E. (2006). Hábitos de práctica de actividad física y estilo de vida saludable del alumnado de la Universidad de Huelva. Huelva. Retrieved from http://rabida.uhu.es/dspace/handle/10272/2644

Celis-morales, C., Salas, C., Leppe, J., Cristi-montero, C., Duran, E., \& Willis, N. (2015). Higher physical activity levels are associated with lower prevalence of cardiovascular risk factors in Chile. Revista Médica de Chile, 143(0), 1435-1443. https://doi.org/10.4067/S0034-98872015001100009 
Consejo Superior de Deportes. (2005). EL MODELO DEL DEPORTE UNIVERSITARIO ESPAÑOL. Retrieved from http://www.csd.gob.es/csd/estaticos/dep-univ/061100_MODELO-DEPORTEUNIVERSITARIO-ESPANOL-Cordoba.PDF

Corbí Santamaría, M. (2017). Motivaciones y barreras del alumnado de la Universidad de Burgos hacia la práctica físico-deportiva y su relación con el servicio ' Deportes ' de la Universidad. Burgos. Retrieved from http://riubu.ubu.es/bitstream/10259/4489/1/Corbi_Santamaría.pdf

CSD. (2010). Plan Integral para la Actividad Física y el Deporte. Libro Del Plan A+D, 141. Retrieved from http://www.csd.gob.es/csd/estaticos/plan-integral/LIBRO-PLAN-AD.pdf

Donnelly, J. E., Honas, J. J., Smith, B. K., Mayo, M. S., Gibson, C. A., Sullivan, D. K., ... Washburn, R. A. (2013). Aerobic exercise alone results in clinically significant weight loss for men and women: Midwest exercise trial 2. Obesity, 21, E219-E228. https://doi.org/10.1002/oby.20145

Fanning, J., Walkup, M., Ambrosius, W., Brawley, L., Ip, E., Marsh, A., \& Rejeski, W. (2018). Change in health-related quality of life and social cognitive outcomes in obese, older adults in a randomized controlled weight loss trial: Does physical activity behavior matter? Journal of Behavioral Medicine, 41(3), 299-308. https://doi.org/10.1007/s10865-017-9903-6

García-Ferrando, M., \& Llopis-Goig, R. (2010). Encuesta sobre los hábitos deportivos en España 2010 - Ideal democrático y bienestar personal. Consejo Superior de Deportes.

Government of Spain. (2007). Organic Law 4/2007, 12 April. Por la que se modifica la Ley Orgánica 6/2001, de 21 de diciembre, de Universidades. Boletín Ofical Del Estado, 89(13 de abril de 2007), 16241-16260. https://doi.org/10.1128/MCB.00493-06

Gómez-López, M. (2005). La actividad físico-deportiva en los centros almerienses de educación secundaria post obligatoria y en la Universidad de Almería. Evolución de los hábitos físico-deportivos de su alumnado. Almería.

Kelley, G. A., Kelley, K. S., Roberts, S., \& Haskell, W. (2012). Combined effects of aerobic exercise and diet on lipids and lipoproteins in overweight and obese adults: A meta-analysis. Journal of Obesity, 2012. https://doi.org/10.1155/2012/985902

Ministerio de Educación Cultura y Deporte. (2015). ENCUESTA DE HÁBITOS DEPORTIVOS EN ESPAÑA 2015. Retrieved from http://www.mecd.gob.es/servicios-al-ciudadanomecd/dms/mecd/servicios-al-ciudadanomecd/estadisticas/deporte/ehd/Encuesta_de_Habitos_Deportivos_2015.pdf

Nakamura, P. M., Teixeira, I. P., Smirmaul, B. P. C., Sebastião, E., Papini, C. B., Gobbi, S., \& Kokubun, E. (2014). Health related quality of life is differently associated with leisure-time physical activity intensities according to gender: A cross-sectional approach. Health and Quality of Life Outcomes, 12, 1-10. https://doi.org/10.1186/1477-7525-12-98

Pavón Lores, A., \& Moreno Murcia, J. A. (2006). Diferencias por edad en el análisis de la práctica físicodeportiva de los universitarios. Cuadernos de Psicología del Deporte, 6(1), 53-67.

REUS. (2011). Red Española de Universidades Saludables. Principios, estructura y objetivos de la red. Retrieved from http://www.mecd.gob.es/dms-static/62a2b7e0-3621-4ff0-bb3aa2a728d6a190/anexoi-pdf.pdf

Rico, J. (2017). Hábitos y motivaciones de práctica de actividad físico-deportiva del Universitario, Alumnado. Vigo. Retrieved from http://www.investigo.biblioteca.uvigo.es/xmlui/bitstream/handle/11093/711/Hábitos_y_motivaciones .pdf? sequence=1\&isAllowed $=y$

Ruiz-Juan, F., \& Gómez-López, M. (2005). Práctica deportiva en los universitarios. In Gymnos (Ed.), Respuestas a la demanda social de actividad física (pp. 143-160). España. 
Ruíz, F. (2001). Análisis diferencial de los comportamientos, motivaciones y demanda de actividades físico-deportivas del alumnado almeriense de enseñanza secundaria post-obligatoria y de la Universidad de Almería. Almería.

Sanz, E. (2005). La práctica físico-deportiva de tiempo libre en universitarios análisis y propuestas de mejora. (U. de La Rioja, Ed.). La Rioja. Retrieved from https://dialnet.unirioja.es/servlet/libro?codigo $=265412$

Song, J. K., Stebbins, C. L., Kim, T. K., Kim, H. B., Kang, H. J., \& Chai, J. H. (2012). Effects of 12 weeks of aerobic exercise on body composition and vascular compliance in obese boys. Journal of Sports Medicine and Physical Fitness, 52, 522-529. 